Jurnal Natur Indonesia 17(1), Oktober 2016: 33-41

ISSN 1410-9379; e-ISSN 2503-0345

\title{
Pengaruh Ukuran Partikel Arang Sekam Padi Dan Waktu Refluks terhadap Kadar Abudan Daya Serap Karbon Sekam Padi
}

\author{
Solihudin"), Atiek Rostika Noviyanti, dan Iman Rahayu \\ Departemen Kimia, Fakultas Matematika dan Ilmu Pengetahuan Alam, Universitas Padjadjaran \\ Jalan Raya Bandung, Sumedang Km 21 Jatinangor, Sumedang, Jawa barat 45363
}

Dietrima 16-09-2016 Disetujui 21-10-2016

\begin{abstract}
The highest content in rice husk is ash with its main component of silica. Silica in ash causes the low adsorption capacity. Activated carbon from rice husk can be obtained by lowering the ash content. The aim of this study is determine the effect of particle size of charcoal and reflux time the ash content using a solution of potassium carbonate. The activation of rice husk char was carried out by using reflux methods with a potassium carbonate solution. The resulted carbon was washed using hydrochloric acid tested using iodine and methylene blue to examine of its adsorbance. The particle size of rice husk and reflux time decrease ash content in rice husk. In general, husk with the size of 80 mesh can produce carbon with low ash content and high absorption using reflux time at least for 120 minutes. Rice husk size of 100 mesh refluxing with potassium carbonate for 150 minutes can reduce the ash content as $91.85 \%$ and adsorptivity of the iodine at $331 \mathrm{mg} . \mathrm{g}^{-1}$.
\end{abstract}

Keywords: activated carbon, iodine numbers, methylene blue numbers, rice husk char

\begin{abstract}
ABSTRAK
Kandungan tertinggi dalam arang sekam padi adalah abu dengan komponen utama silika yang menyebabkan kapasitas adsorpsinya rendah. Karbon aktif dari sekam padi dapat diperoleh dengan cara menurunkan kadar abunya. Penelitian ini bertujuan untuk menentukan pengaruh ukuran partikel arang dan waktu refluks dengan larutan kalium karbonat terhadap penurunan kadar abu dan peningkatan daya serapnya. Metode yang digunakan untuk pemurnian arang sekam padi adalah metode refluks dengan larutan kalium karbonat. Karbon hasil refluks dicuci dengan menggunakan asam klorida. Karbon yang diperoleh diuji kadar abu dan daya serapnya terhadap iodin dan metilen biru. Ukuran partikel arang sekam padi dan waktu refluks sangat berpengaruh terhadap penurunan kadar abu. Secara umum arang sekam yang lolos pada ayakan berukuran 80 mesh dapat menghasilkan karbon dengan kadar abu rendah dan daya serap tinggi dengan waktu refluks minimal 120 menit. Proses refluk dengan kalium karbonat yang dilanjutkan pencucian dengan asam klorida pada arang sekam padi 100 mesh dengan waktu refluks 150 menit dapat menurunkan kadar abu sebesar $91,85 \%$ dengan daya serap terhadap iodin $331 \mathrm{mg} \cdot \mathrm{g}^{-1}$.
\end{abstract}

Kata kunci: Arang sekam padi, bilangan iodin, bilangan metilen biru, karbon aktif

\footnotetext{
*Telp: +628122000405

Email: solihin@unpad.ac.id
} 


\section{PENDAHULUAN}

Sebagian besar sekam merupakan senyawa karbon (organik) yang meliputi selulosa, hemiselulosa dan lignin sehingga dapat digunakan untuk bahan bakar yang merata dan stabil. Densitas ruah sekam padi sangat rendah $\left(0,100 \mathrm{~g} \cdot \mathrm{cm}^{-3}\right)$ menjadi masalah tersendiri terutama dalam hal transportasi. Pemanfaatan sekam padi sebagai bahan bakar yang telah banyak digunakan adalah untuk bahan bakar pada pembakaran bata merah. Pemakaian sekam padi sebagai bahan bakar karena lebih murah dan bila asapnya didistilasi memberikan nilai tambah dari distilat asapnya yang dapat digunakan sebagai pestisida atau bahan pengawet. Sekam padi sebagai sumber energi saat ini banyak dimanfaatkan memalui proses gasifikasi. Pada proses gasifikasi ini menghasilkan arang dengan kadar abu yang sangat tinggi, sehingga tidak dapat secara langsung digunakan sebagai bahan karbon aktif.

Proses aktivasi arang sekam padi secara fisik tidak membentuk karbon aktif yang mempunyai luas permukaan tinggi. Karbon aktif dari arang sekam padi mempunyai luas permukaan tinggi umumnya diperoleh dengan cara menghilangkan silika dalam arang yang dapat dilakukan sebelum atau sesudah karbonisasi. Hieu et al. (2015) telah melakukan pemisahan silika dari abu sekam padi yang mengandung silika sekitar $45 \%$ dengan menggunakan larutan natrium hidroksida $6 \mathrm{M}$ dengan perbandingan massa alkali/abu 0,6 dan suhunya $133^{\circ} \mathrm{C}$, pada penelitian tersebut perolehan silika mencapai 95,6\%. Muniandy (2014) membuat karbon aktif dari sekam padi dengan cara aktivasi arang sekam padi dengan aktivator natrium hidroksida dan kalium hidroksida. Aktivasi dengan kalium hidroksida menghasilkan karbon aktif dengan luas permukaan sekitar $2696 \mathrm{~m}^{2} \cdot \mathrm{g}^{-1}$. Pada penelitian lain dengan menggunakan natrium hidroksida sebagai pelepas silika dan aktivatornya kalium hidroksida menghasilkan karbon dengan luas permukaan $2696 \mathrm{~m}^{2} \cdot \mathrm{g}^{-1}$ dan kapasitansi spesifiknya 147 F.g $^{-1}$ (Teoa et al. 2016). Sedangkan Liu et al. (2016) melakukan impregnasi kalium hidroksida pada arang sekam padi dan diaktivasi pada suhu $700^{\circ} \mathrm{C}$ selama 1 jam menghasilkan arang dengan luas permukaan $3263 \mathrm{~m}^{2} \cdot \mathrm{g}^{-1}$, dan kapasitansi spesifiknya $330 \mathrm{~F}_{\mathrm{g}} \mathrm{g}^{-1}$. Yeletsky et al. (2009) menggunakan aktivator kalium karbonat dengan suhu aktivasi $900^{\circ} \mathrm{C}$ menghasilkan karbon aktif dengan luas permukaan maksimum $1676 \mathrm{~m}^{2} \cdot \mathrm{g}^{-1}$.
Berdasarkan uraian di atas menunjukkan bahwa arang sekam padi dapat digunakan sebagai bahan dasar untuk membuat karbon aktif melalui pembentukan karbon berpori. Seperti yang diuraikan dalam beberapa literatur menunjukkan masih adanya kelemahan dalam pembuatan karbon aktif seperti prosesnya yang masih rumit dan tidak ramah lingkungan. Pada penelitan sebelumnya telah berhasil mengaktivasi arang sekam padi dengan metode yang sederhana dan ramah lingkungan yaitu menggunakan larutan natrium karbonat dengan metode refluks dapat menurunkan kadar abu dari 54\% menjadi 28,54\% (Solihudin et al. 2015). Kadar abu yang diperoleh masih relatif tinggi sehingga belum memenuhi syarat sebagai karbon aktif. Penelitian yang akan dilakukan yaitu melalui proses karbonisasi sekam padi yang dilanjutkan dengan proses aktivasi menggunakan larutan kalium karbonat dengan ukuran partikel arang yang diragamkan. Pada proses yang akan diteliti ini diharapkan dapat diperoleh karbon dengan kadar abu yang redah. Selain itu larutan kalium karbonat dari proses refluks dapat diperoleh silika dan larutan kalium karbonat yang telah digunakan juga dapat diambil kembali (Liu et al. 2012). Silika yang diperoleh dapat digunakan untuk membuat berbagai bahan dasar silika seperti silika gel, silika koloid, pendukung katalis, zeolit, silika mesopori dan lain-lain.

\section{BAHAN DAN METODE}

Bahan-bahan yang digunakan meliputi sekam padi (dari penggilingan padi di Jatinangor, Sumedang), kalium karbonat, asam klorida pa, kristal iodin, dan biru metilena. Alat-alat yang digunakan meliputi alat refluks, cawan porselin, dan spektrofotometer UV-Vis.

Eksperimen. Karbonisasi Arang Sekam Padi. Arang sekam padi diperoleh dengan cara pengarangan sekam padi pada suhu $400^{\circ} \mathrm{C}$ selama 6 jam. Arang sekam padi selanjutnya dikalsinasi pada suhu $700^{\circ} \mathrm{C}$ sambil dialiri gas argon selama $4 \mathrm{jam}$. Setelah didinginkan, arang sekam padi digerus hingga lolos pada ayakan 20, 50, 80, 100, dan 200 mesh (20, 50, 90, 100, dan 200 mesh).

\section{Aktivasi dengan Larutan Kalium Karbonat. Arang} sekam padi yang telah dihaluskan sesuai dengan ukuran yang diinginkan ditimbang sebanyak $5 \mathrm{~g}$ dan dimasukkan ke dalam labu didih. Setelah itu, ditambahkan kalium karbonat dan akuades dengan perbandingan mol 1:3:150 
(silika : kalium karbonat : air), kemudian direfluks dengan variasi waktu 30, 60, 90, 120, 150, dan 180 menit. Campuran disaring dalam keadaan panas dengan corong buchner menggunakan kertas saring whatman No. 42 dan dibilas dengan akuades panas hingga bebas dari karbonat. Residu yang diperoleh dikeringkan, dicuci dengan larutan asam klorida $1 \mathrm{~N}$ dan dibilas dengan akuades sampai bebas ion klorida. Residu yang diperoleh di keringkan pada suhu $110^{\circ} \mathrm{C}$ selama $12 \mathrm{jam}$.

Penentuan Kadar Abu. Cawan dipanaskan di dalam tanur pada suhu $800^{\circ} \mathrm{C}$ selama 1 jam, didinginkan dan ditimbang (massa cawan kosong). Sampel ditimbang sebanyak 0,2 g, dimasukkan ke dalam cawan lalu dipanaskan di dalam tanur pada suhu $600^{\circ} \mathrm{C}$ selama $1 \mathrm{jam}$ dan $800^{\circ} \mathrm{C}$ selama $1 \mathrm{jam}$. Setelah dingin cawan ditimbang kemudian dihitung kadar abunya.

Penentuan Daya Serap Karbon terhadap Larutan Iodin. Padatan iodin $\left(\mathrm{I}_{2}\right)$ ditimbang $12,9158 \mathrm{~g}$ dan padatan kalium iodida (KI) 18,0213 g, dilarutkan dengan $200 \mathrm{~mL}$ akuades dalam labu ukur $1 \mathrm{~L}$, dan diencerkan hingga volume $1 \mathrm{~L}$. Larutan iodin distandarkan dengan larutan standar natrium tiosulfat.

Sampel karbon dipanaskan terlebih dahulu pada suhu $110^{\circ} \mathrm{C}$ selama 2 jam di dalam oven. Sampel ditimbang sebanyak $1 \mathrm{~g}$ dan ditambahkan larutan iodin sebanyak $32 \mathrm{~mL}$ di dalam botol kocok. Botol ditutup dan dikocok menggunakan pengocok pada $180 \mathrm{rpm}$ selama 15 menit. Larutan iodin di dalam botol diambil sebanyak $10 \mathrm{~mL}$ menggunakan syringe. Larutan iodin dititrasi dengan larutan standar natrium tiosulfat $0,1 \mathrm{~N}$.

\section{Penentuan Daya Serap Karbon terhadap Larutan} metilen biru. Biru metilena ditimbang sebanyak 1,2017 g lalu dilarutkan dengan akuades hingga volume $1 \mathrm{~L}$, larutan biru metilena 1.201 ppm. Larutan biru metilena didiamkan selama 24 jam. Larutan biru metilena diambil sebanyak $83,26 \mathrm{~mL}$ dan ditambahkan $5 \mathrm{~mL}$ asam asetat $0,00125 \%$ lalu diencerkan hingga $1 \mathrm{~L}$ (larutan biru metilena 100 ppm). Masing-masing karbon ditimbang $50 \mathrm{mg}$ dimasukkan ke dalam labu erlenmeyer, kemudian ditambahkan sedikit demi sedikit menggunakan larutan metilen biru, untuk melihat daya serap karbon aktif terhadap larutan metilen biru. Setelah ditambahkan larutan metilen biru, wadah dikocok dan didiamkan selama 5 menit, lalu dilihat warna dari larutan. Bila larutan masih terlihat tidak berwarna, ditambahkan sedikit volume metilen biru. Penambahan volume dihentikan saat warna dari larutan menjadi biru muda. Larutan biru muda pada wadah diukur absorbansinya menggunakan instrumen spektofometer UV-Vis pada panjang gelombang $664 \mathrm{~nm}$. Konsentrasi larutan dihitung.

\section{HASIL DAN PEMBAHASAN}

\section{Refluks dengan Larutan Kalium Karbonat. Refluks}

dengan larutan kalium karbonat dilakukan pada variasi ukuran partikel dari arang sekam padi dan variasi waktu refluks. Kalium karbonat dalam air akan terionisasi membentuk ion karbonat $\left(\mathrm{CO}_{3}{ }^{2-}\right)$ yang akan terhidrolisis seperti persamaan reaksi 1 . Reaksi hidrolisis tersebut dipengaruhi suhu, makin tinggi suhu larutan ion hidroksida $\left(\mathrm{OH}^{-}\right)$makin tinggi sehingga jumlah silika yang larut semakin banyak (sebagai silikat) seperti ditunjukkan oleh persamaan reaksi 2. Apabila suhu diturunkan akan menggeser reaksi ke arah kiri sehingga jumlah ion hirodksida akan berkurang dan ion silikat akan menjadi silika yang mengendap. Supaya silika tidak mengendap sebelum karbonnya dipisahkan maka pada proses penyaringan suhu campuran harus dijaga sedemikian rupa di atas $80^{\circ} \mathrm{C}$.

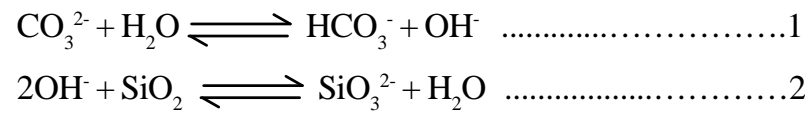

Silika merupakan komponen utama yang terkandung dalam abu sekam padi. Kandungan silika dalam abu sekam padi dapat mencapai $95 \%$ atau lebih tergantung pada varietas dan lokasi penanaman padi, dengan demikian pelarutan silika akan menurunkan kadar abu dalam arang sekam padi sangat tinggi, selain itu kandungan logam alkali juga akan berkurang karena alkali karbonat juga ikut terlarut. Garam-garam karbonat selain garam alkali tidak larut dalam air sehingga karbon hasil refluk dengan karbonat masih mengandung logam seperti kalsium, alumunium, besi, magnesium dan logam selain alkali lainnya. Supaya kadar abunya lebih rendah lagi maka perlu dilakukan pencucian kembali dengan larutan asam, dalam penelitian ini menggunakan asam klorida. 
Pengaruh Waktu Refluks dengan Larutan Kalium Karbonat dan Ukuran Partikel Arang Sekam Padi terhadap Penurunan Kadar Abu. Sekam padi yang digunakan pada penelitian ini berasal dari penggilingan padi yang ada di Jatinangor, Kabupaten Sumedang. Sekam padi yang digunakan mengandung kadar abu 24,46\% dan setelah diarangkan kadar abunya 50,43\%. Arang sekam padi dengan ukuran partikel yang diragamkan (20, 50, 90, 100, dan 200 mesh) masing-masing direfluks dengan larutan kalium karbonat pada variasi waktu 30; 60; 90; 120; 150; dan 180 menit. Variasi waktu ini dilakukan untuk menentukan waktu refluks optimum yang diperlukan sehingga diperoleh karbon dengan kadar abu paling sedikit. Hasil pengukuran kadar abu pada variasi ukuran partikel dan waktu refluk dapat dilihat pada Gambar 1. Pada Gambar 2 dapat dilihat bahwa hasil refluk mulai dari 120 menit nampak perubahannya kecil dan kadar abu pada karbon sudah dibawah $10 \%$, kecuali pada arang yang berukuran -20 mesh dengan waktu refluk optimum 150 menit.

Pada Gambar 1 juga dapat dilihat bahwa pada ukuran 20 mesh kadar abu pada karbonnya relatif jauh berbeda dengan ukuran lainnya untuk setiap waktu refluksnya. Hal tersebut disebabkan karena pengotor masih banyak yang terkurung di dalam partikelnya sehingga tidak dapat kontak dengan larutannya. Mulai dari ukuran partikel 50 mesh nampak kadar abunya tidak jauh berbeda untuk setiap waktu refluknya. Silika pada sekam padi terutama berada pada lapisan luarnya sehingga ketika dihaluskan sampai ukuran tertentu silika akan berada di luar atau pada permukaan partikel karbon (Solihudin 2011). Makin kecil ukuran partikel kemungkinan pengotor berada di luar atau pada permukaan partikel arang makin banyak sehingga mudah terjadi kontak dengan larutan dan akan larut. Namun pada Gambar 1 terlihat bahwa pengaruh ukuran partikel terhadap kadar abu pada karbon hasil refluksnya tidak beraturan. Hal tersebut kemungkinan disebabkan pada proses penyaringan terjadi pendinginan yang tidak teratur sehingga terjadi pengendapan silika yang akan menambah kadar abu pada karbonnya. Kadar abu pada karbon dengan ukuran 50 mesh sampai 200 mesh berkisar antara 7-9\% dengan kadar terkecil umumnya diperoleh pada hasil refluks dari 100 mesh. Bila dibandingkan dengan dengan hasil ekstraksi dengan natrium karbonat (Solihudin et al. 2015), kadar abu dalam karbon sekam padi jauh lebih kecil

Pemurnian Karbon. Karbon yang dihasilkan harus mengandung abu sangat kecil, menurut Masitoh \& Sianita (2013) kadar abu dalam karbon aktif dapat mengganggu proses adsorpsi karena kandungan abu yang berlebihan dapat menyebabkan terjadinya penyumbatan pori-pori karbon aktif sehingga menurunkan kemampuan adsorpsinya. Abu yang masih terkandung dalam karbon hasil refluks merupakan oksida logam dan silika yang tidak larut pada saat refluks dan pencucian karena terkurung di bagian dalam karbon atau pori-pori. Oksida logam yang tidak larut pada proses refluks dapat dilarutkan dengan

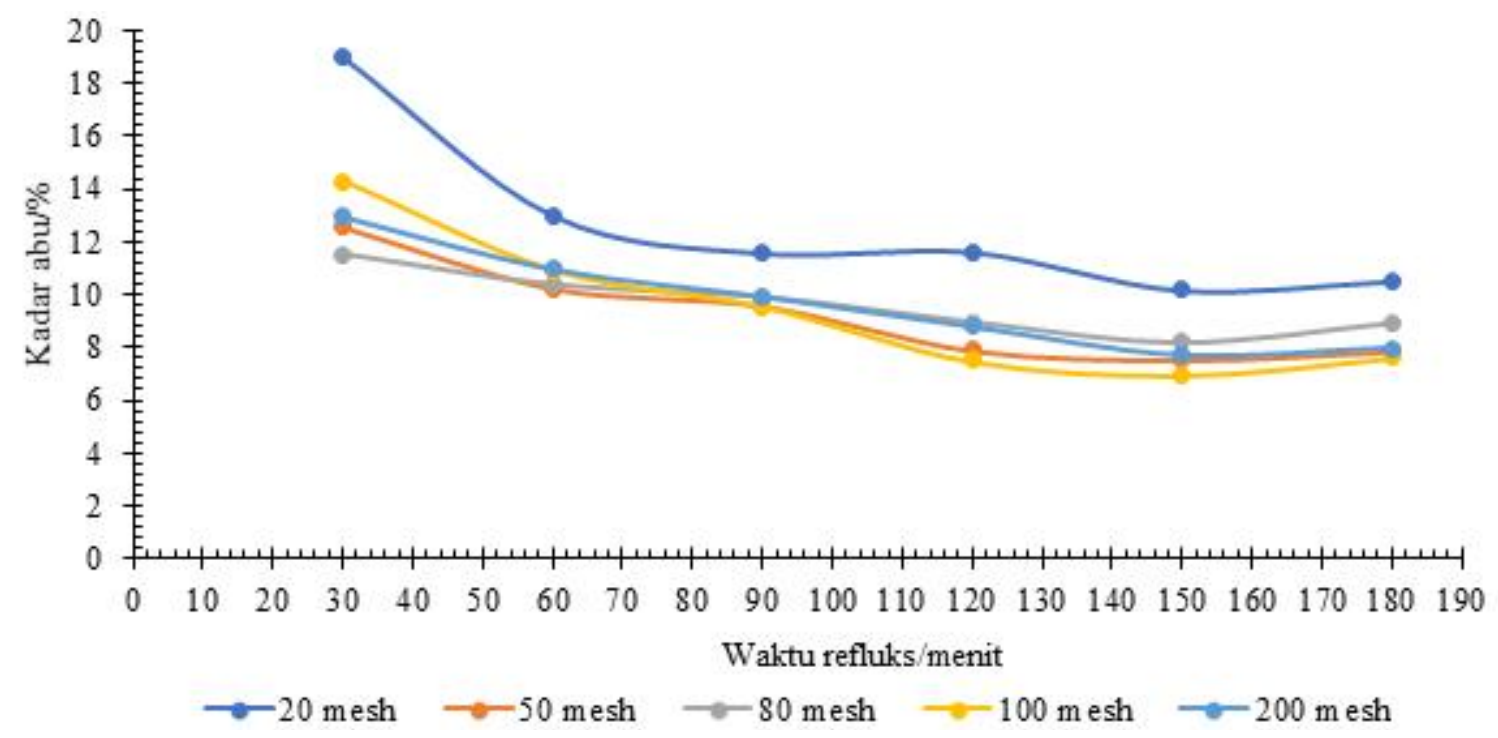

Gambar 1 Grafik waktu refluks dari arang sekam padi dengan ukuran partikel 100 mesh terhadap presentase silika yang dihasilkan 


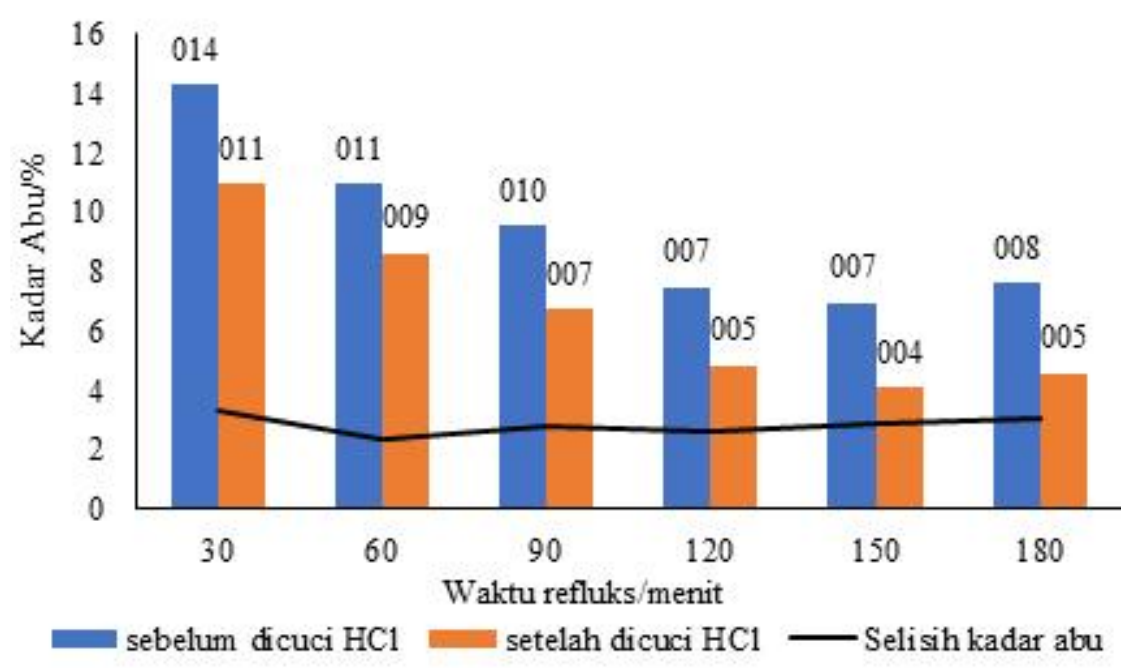

Gambar 2 Kadar abu karbon hasil pemurnian dengan asam klorida pada ukuran partikel 100 mesh

menggunakan larutan asam, pada penelitian ini menggunakan asam klorida $1 \mathrm{M}$ dan dilakukan terhadap karbon dari arang ukuran partikel 100 mesh. Kadar abu sebelum dan sesudah pencucian dicantumkan pada Gambar 2.

Pada Gambar 2 tersebut terlihat bahwa setelah pemurnian dengan asam terjadi penurunan kadar abu yang relatif sama yaitu berkisar 2,6\% sampai 3,3\%. Kadar abu terkecil pada karbon hasil pemurnian adalah $4,11 \%$ yang berasal dari arang pada ukuran -100 mesh dengan waktu refluk 150 menit. Pemurnian menggunakan asam klorida ini dapat melarutkan logam-logam karena hampir semua garam klorida dapat larut dalam air. Dengan demikian jumlah abu yang hilang setelah sampai pencucian dengan asam klorida 1 M mencapai 91,85\%.

Daya Serap Karbon Terhadap Iodin. Karbon hasil refluks dan pencucian dengan asam klorida dari arang sekam padi kemudian dikarakterisasi daya serap terhadap iodin. Suhendarwati (2014) mengatakan bahwa daya serap terhadap larutan iodin (bilangan iodin) ditentukan dengan tujuan mengetahui kemampuan adsorpsi terhadap bau. Semakin tinggi bilangan iodin maka semakin baik kualitas karbon aktif. Selain itu, bilangan iodin ini untuk mengetahui kemampuan kualitas karbon aktif dalam menyerap zat dengan ukuran molekul lebih kecil. Pada penelitian ini, penentuan bilangan iodin karbon menggunakan metode sesuai dengan SNI 06-3730-1995. Bilangan iodin tersebut dapat ditunjukkan oleh banyaknya iodium yang diserap oleh karbon yang diuji, semakin banyak iodium yang diserap oleh sampel uji maka semakin besar pula daya adsorpsi dari karbon yang diuji. Pada Gambar 3 tampak bahwa waktu refluks relatif tidak berpengaruh terhadap bilangan iodium kecuali pada karbon yang berasal dari arang ukuran partikel 80 mesh. Selain itu juga tampak bahwa daya adsorpsinya mulai meningkat nyata pada karbon yang berasal dari arang ukuran 100 mesh dan 200 mesh dengan bilangan iodin yang relatif sama yaitu berkisar antara 315 sampai $335 \mathrm{mg} \cdot \mathrm{g}^{-1}$. Iodin selain dapat diserap oleh permukaan arang juga dapat terserap pada pori-porinya karena iodin mempunyai ukuran yang relatif kecil sehinngga iodin yang berada dalam larutan dapat masuk ke mikropori.

\section{Daya Serap Karbon Aktif Terhadap Metilen Biru.}

Percobaan daya serap karbon aktif terhadap biru metilena (bilangan metilen biru) ini sering diidentikan untuk mengetahui daya serap karbon terhadap zat warna organik. Biru metilena juga sering digunakan untuk estimasi luas permukaan padatan, namun biru metilena ini mempunyai ukuran molekul yang besar sehingga pada arang aktif hanya menunjukkan luas permukaan di luar pori-pori. Hasil pengukuran bilangan biru metilena pada karbon sekam padi tercantum pada Gambar 4. Pada Gambar 4 tampak waktu refluks relatif tidak mempengaruhi daya serap karbon terhadap biru metilena karena adsorpsi biru metilena pada karbon terjadi pada permukaan di luar pori-pori (dalam hal ini terutama mikropori). Sedangkan ukuran partikel sangat mempengaruhi daya serap terhadap biru metilena karena makin kecil ukuran partikel luas permukaan akan makin 


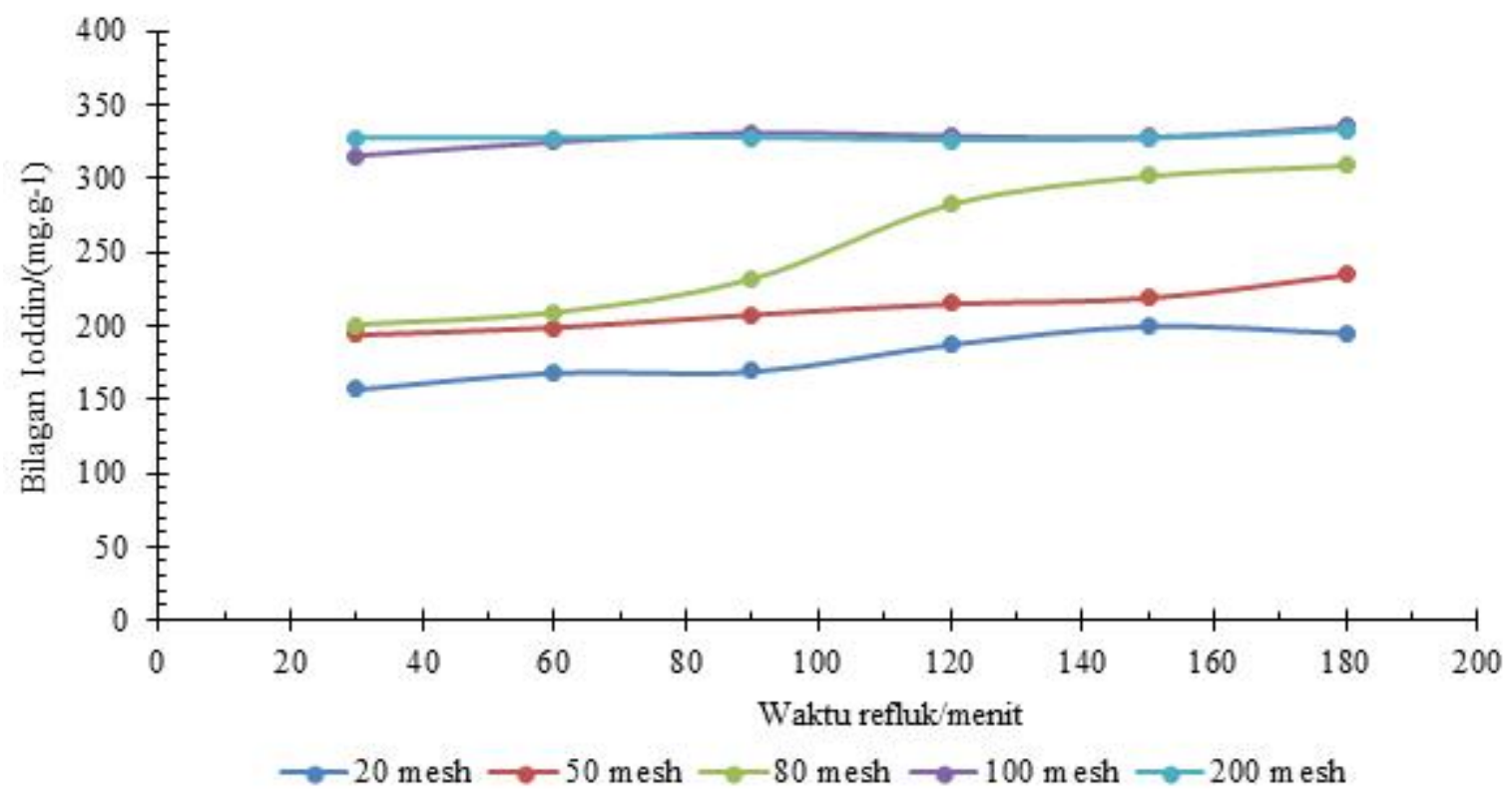

Gambar 3 Daya serap karbon aktif terhadap iodin

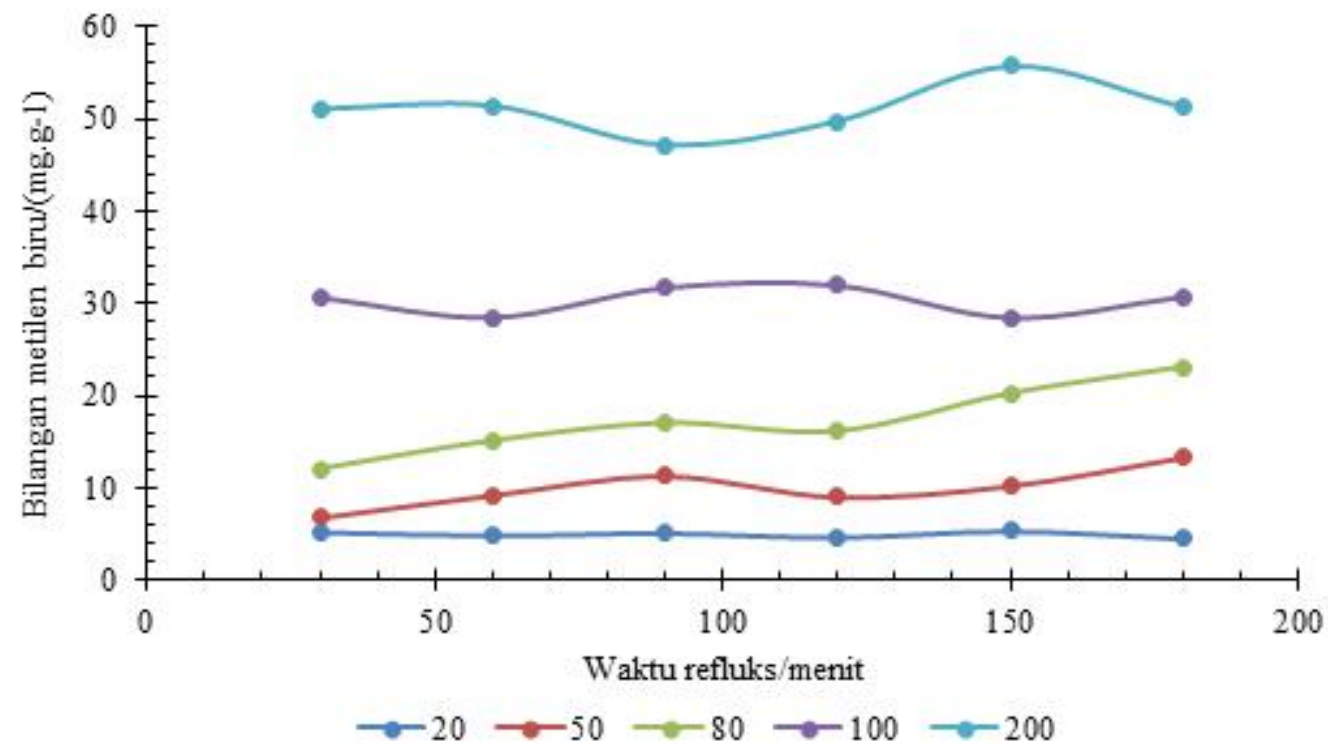

Gambar 4 Daya serap karbon aktif terhadap metilen biru

besar sehingga karbon dari arang ukuran -200 mesh mempunyai daya serap terhadap biru metilena paling besar yaitu berkisar antara 47 sampai $56 \mathrm{mg} \cdot \mathrm{g}^{-1}$.

Luas Permukaan dan Volume Pori. Hubungan luas permukaan, volume total pori dan volume mikropori hasil pengukuran adsorpsi gas nitrogen (metode BET) dengan bilangan iodin dan bilangan biru metilena pada karbon aktif telah dikemukakan oleh Nunes \& Guerreiro (2011) seperti pada persamaan 3, 4, dan 5. Berdasarkan persamaan tersebut luas permukaan karbon dari arang pada berbagai variasi ukuran partikel arang dan waktu refluks tercantum pada Gambar 5. Pada Gambar 5 tampak bahwa makin kecil ukuran partikel luas permukaan makin tinggi, namun pada karbon dari arang ukuran partikel 100 dan 200 mesh relatif sama. Luas permukaan dan nilai bilangan iodin juga relatif sama, hal ini sesuai juga dengan hasil penelitian Mianowski et al. (2007) yang menyatakan bilangan iodin sama dengan luas permukaan hasil pengukuran adsorpsi menggunakan gas argon. Pada penelitian ini luas permukaan karbon masih sangat rendah bila dibandingkan dengan penelitian lain karena karbon yang diperoleh belum dikalsinasi. Yeletsky 


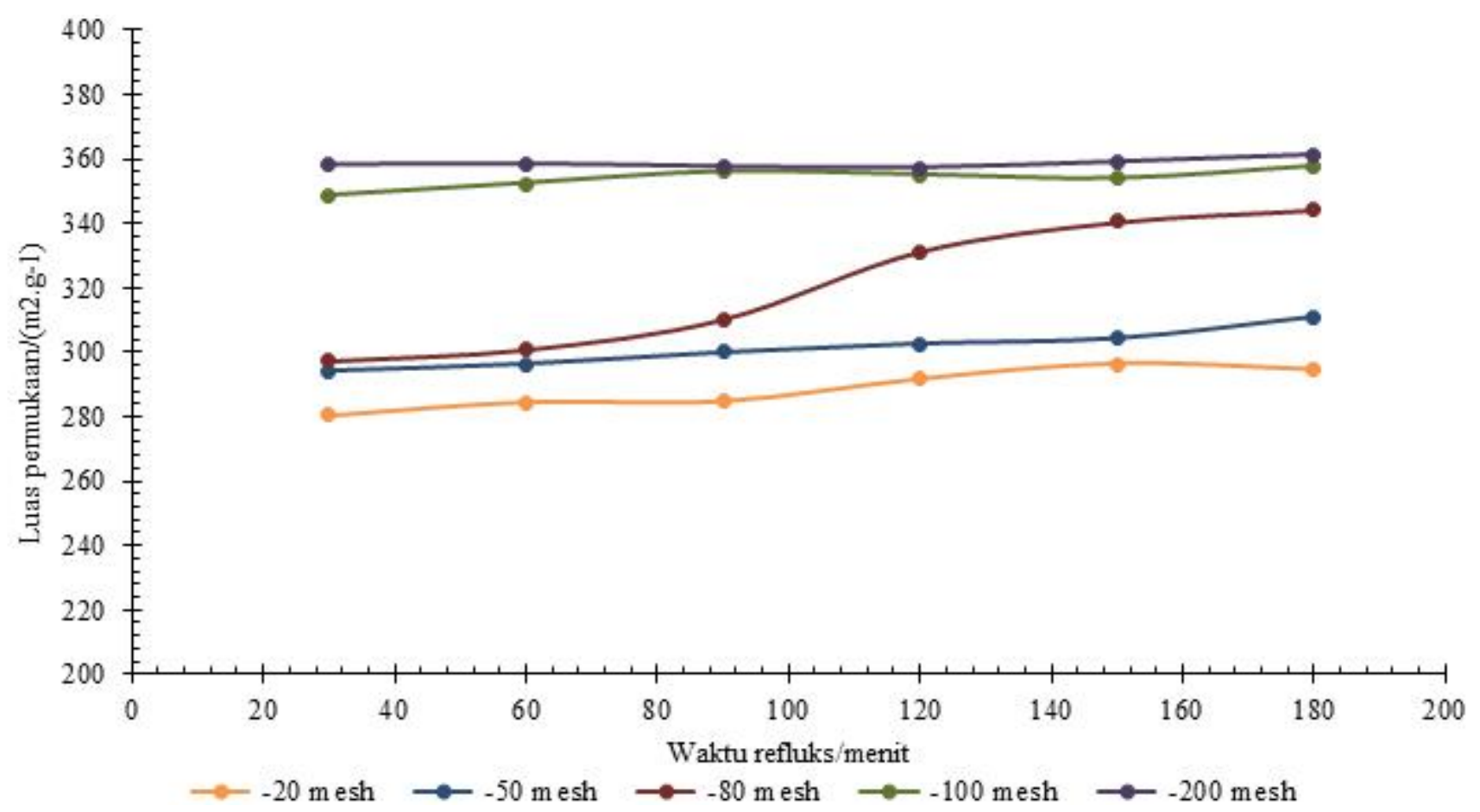

Gambar 5 Hasil perhitungan luas permukaan

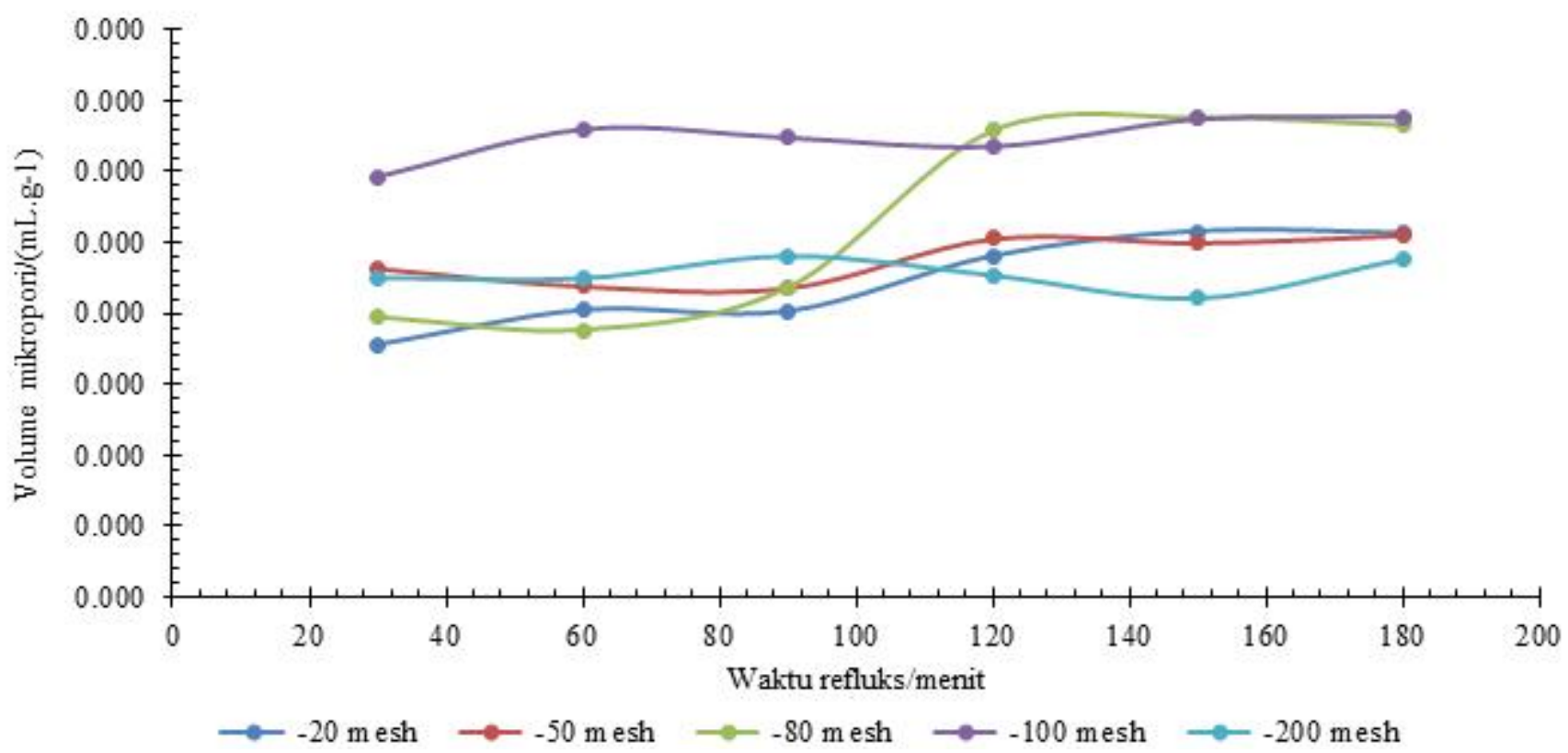

Gambar 6 Hasil perhitungan volume mikropori

et al. (2009) melakukan kalsinasi pada suhu $900^{\circ} \mathrm{C}$ diperoleh luas permukaan karbon sebesar $1676 \mathrm{~m}^{2} \cdot \mathrm{g}^{-1}$.

$\mathrm{S}\left(\mathrm{m}^{2} \cdot \mathrm{g}^{-1}\right)=228-0,101 \mathrm{XMBN}+0.3 \mathrm{XIN}+0,000105 \mathrm{X} \mathrm{MBN}^{2}$ $+0,0002 \mathrm{XIN}^{2}+0,000938 \mathrm{XMBN}$ . .3

$\operatorname{Vm}\left(\left(\mathrm{cm}^{3} \cdot \mathrm{g}^{-1}\right)=0.056-0.001 \mathrm{X} \mathrm{MBN}+0.000155 \mathrm{X} \mathrm{IN}+\right.$ $0.000007 \mathrm{X} \mathrm{MBN}^{2}+0.0000001 \mathrm{XIN}^{2}-0.000000118 \mathrm{XMBNX}$ IN ...4
$\operatorname{Vt}\left(\left(\mathrm{cm}^{3} \cdot \mathrm{g}^{-1}\right)=0.137+0.0019 \mathrm{X} \mathrm{MBN}+0.0001 \mathrm{X} \mathrm{IN}\right.$ .5

$\mathrm{S}$ adalah luas permukaan sesuai pengukuran dengan gas nitrogen metode BET, MBN: bilangan metilen biru, IN: bilangan iodin, Vm: volume mikropori dan Vt: volume total pori. 


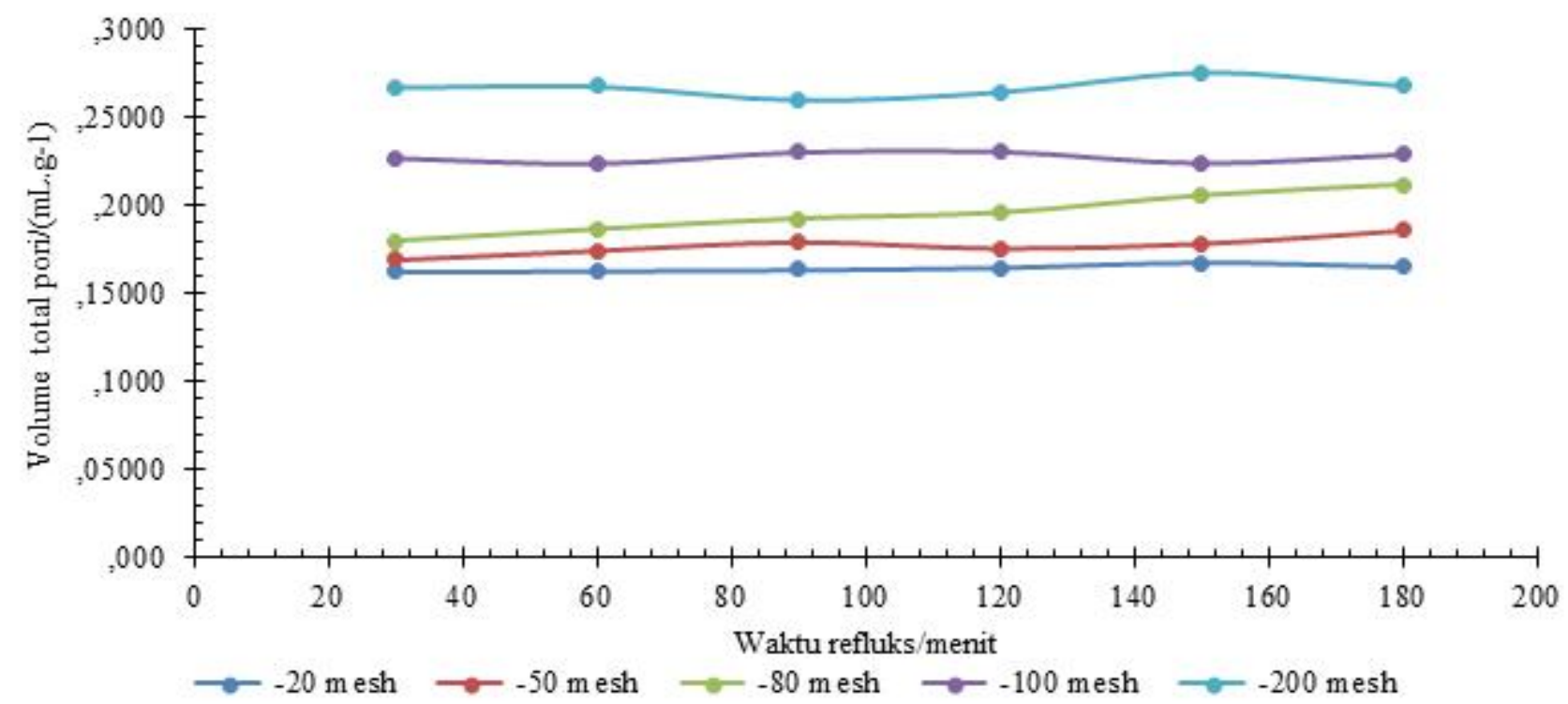

Gambar 7 Hasil perhitungan volume total pori

Hasil perhitungan volume mikropori dengan penggunakan persamaan 4 dicantumkan pada Gambar 6 . Pada Gambar 6 tampak bahwa karbon dari arang -100 mesh pada umumnya mempunyai volume mikropori yang paling besar, hal tersebut sesuai dengan bilangan iodin yang besar juga dengan bilangan biru metilena yang lebih rendah dari ukuran -200 mesh. Besarnya bilangan biru metilena menunjukkan penyerapan biru metilena terjadi pada permukaan.

Hasil perhitungan volume mikropori dengan penggunakan persamaan 5 dicantumkan pada Gambar 7 . Pada Gambar 7 tampak bahwa karbon dari arang ukuran partikel -200 mesh mempunyai volume total pori paling tinggi. Besarnya volume total dengan volume mikropori yang rendah menunjukkan adanya mesopori yang cukup besar, hal ini sangat penting dalam proses adsorpsi pada sistem larutan.

\section{SIMPULAN}

Ukuran partikel arang sekam padi dan waktu refluks sangat berpengaruh terhadap penurunan kadar abu dan silika. Secara umum arang sekam padi dapat dibuat karbon yang mempunyai kadar abu rendah dengan daya serap tinggi dengan cara refluks menggunakan larutan kalium karbonat pada ukuran partikel mulai dari -80 mesh dengan waktu refluks minimal 120 menit. Proses refluk dengan kalium karbonat yang dilanjutkan pencucian dengan asam klorida pada arang sekam padi 100 mesh dengan waktu refluks 150 menit dapat menurunkan kadar abu sebesar $91,85 \%$ dan daya adsorpsi terhadap iodin mencapai 331 mg. $\mathrm{g}^{-1}$ setara dengan luas permukaan $358 \mathrm{~m}^{2} \cdot \mathrm{g}^{-1}$.

\section{UCAPAN TERIMA KASIH}

Ucapan terima kasih yang sebesar-besarnya pada PROGRAM ACADEMIC LEADERSHIPS GRANT 1-1-6, ALG Unpad yang telah membiayai penelitian memgenai Pemanfaatan Sekam Padi sebagai Sumber Material dalam Aplikasi Energi Terbarukan (Nomor 158/UN6.D/Kep/ FMIPA/2016)

\section{DAFTAR PUSTAKA}

Hieu, N.M., Korobochkin, V.V \&Tu, N.V. 2015. A study of silica separation in the production of activated carbon from rice husk in Viet Nam. Procedia Chemistry 15: 308-312.

Liu Y., Guo Y., Gao W., Wang Z., Yuejia Ma \& Wang Z. 2012. Simultaneous preparation of silica and activated carbon from rice husk ash. Journal of Cleaner Production 32: 204-209.

Liu, D., Zhang, W., Lin, H., Li, Y., Lu, H \& Yan, Y. 2016. A green technology for the preparation of high capacitance rice husk-based activated carbon. Journal of Cleaner Production 112: 1190-1198.

Masitoh, F.Y \& Sianita, B.M.M. 2013. Pemanfaatan arang aktif kulit buah coklat (Theobroma cacao L.) Sebagai adsorben logam berat Cd (II) dalam pelarut air. Unesa Journal of Chemistry 2(2): 23-27. 
Mianowski, A., Owczarek. M \& Marecka. 2007. Surface Area of Activated Carbon Determined by the Iodine Adsorption Number. Energy Sources, Part A 29: 839850.

Muniandy, L., Adam, F., Mohamed,A. R \& Ng, E. P. 2014. The synthesis and characterization of high purity mixed microporous/mesoporous activated carbon from rice husk using chemical activation with $\mathrm{NaOH}$ and KOH. Microporous and Mesoporous Materials 197: 316-323.

Nunes, C.A \& Guerreiro, M. C. 2011. Estimation of Surface Area and Pore Volume of Activated Carbons by Methylene Blue and Iodine Numbers. Quim. Nova 34(3): 472-476.

Solihudin 2011. Sintesis dan Karakterisasi Komposit Karbon/Silikalit-1 Berbahan Dasar Sekam Padi. Disertasi. Bandung: Unpad.
Solihudin, Noviyanti, A.R \& Rukiah 2015. Aktivasi arang sekam padi dengan larutan natrium karbonat dan karakterisasinya. JCNA 3(1): 11-16.

Suhendarwati L., Suharto, B \& Dewi L.S. (2014). Pengaruh konsentrasi larutan kalium hidroksida pada abu dasar ampas tebu teraktivasi. Jurnal Sumber Daya Alam dan lingkungan 1(1): 19-25.

Teoa, E. Y. L., Muniandy, L., Ng, E. P., Adam, F., Mohamed, A. R., Jose, R \& Chong, K. F. 2016. High surface area activated carbon from rice husk as a high performance supercapacitor electrode. Electrochimica Acta 192: 110-119.

Yeletsky, P.M . ,Yakovlev ,V.A., M el'gunov, M .S \& Parmon, V.N. 2009. Synthesis of mesoporous carbons by leaching out natural silica templates of rice husk. Microporous and Mesoporous Materials 121: 3440. 